4. Воровщиков С.Г. Специфика учебно-познавательной деятельности как разновидности учения школьников//Преподаватель ХХІ век. 2009. № 4. С. 16-27.

5. Зимняя И.А. Педагогическая психология: учебник для вузов. Изд. 2-е, доп., испр. и перераб. М.: ЛОГОС, 2000. 384 с.

6. Матяш Н.В. Инновационные педагогические технологии: Проектное обучение. 2-е изд., доп. М.: Академия, 2012. 160 c.

7. Окунев А.А. Спасибо за урок, дети. М.: Просвещение, 2010. 163 с.

8. Поливанова К.Н. Проектная деятельность школьников. 2-е изд. М.: Просвещение, 2011. 192 с.

9. Сергейчик Е.М. Философские основания антропологического подхода в постнеклассической науке // Вестник Северного (Арктического) федерального университета. Серия: Гуманитарные и социальные науки. 2018. № 3. С. 70-82.

\title{
Торшина А.B. \\ Педагогический потенциал клубной деятельности подростков Оренбуржья: история и современность
}

Новотроиџкий филиал ФГАОУ ВО «Наџиональный исследовательский технологический университет «МИСиС»

(Россия, Новотроиик)

doi: 10.18411/scienceconf-11-2021-16

\section{Аннотация}

В статье раскрывается педагогический потенциал клубной деятельности подростков Оренбуржья в 1930 - 1950-е годы для современной практики дополнительного образования, заключающиеся в образовательных, личностноориентированных и социально-педагогических позициях.

Ключевые слова: клубная деятельность подростков, Оренбуржье, дополнительное образование; образовательные, личностно-ориентированные, социально-педагогические возможности.

\section{Abstract}

The article reveals the pedagogical potential of the club activity of Orenburg teenagers in the 1930s - 1950s for the modern practice of additional education, consisting in educational, personality-oriented and socio-pedagogical positions.

Keywords: club activity of teenagers, Orenburg region, additional education; educational, personality-oriented, socio-pedagogical opportunities.

В настоящее время актуализируется потребность создания (реконструкции) культурно-досуговых организаций клубного типа, содействия развитию дополнительного образования и социализации детей, в том числе за счет увеличения количества действующих клубов патриотической, спортивной и волонтерской направленности, воссоздания и поддержки сети клубов (детско-взрослых, подростковых) по месту жительства.

Использование категории «потенциал» в педагогической теории и практике предполагает выявление его сущности, содержания и структуры. Под потенциалом в научной литературе понимают возможности. Возможности представляют собой средства, условия, обстоятельства, необходимые для осуществления чего-нибудь [1].

При выявлении педагогического потенциала клубной деятельности подростков Оренбуржья в 1930-1950-е годы для современной практики дополнительного образования мы основывались на положении о том, что историко-педагогическое знание выступает«гарантом качества современной образовательной системы России в период ее активной модернизации» (А.М. Аллагулов) [2].

Педагогический потенциал клубной деятельности подростков Оренбуржья в 1930 - 1950-е годы для современной практики дополнительного образования, 
заключается в образовательных, личностно-ориентированных и социальнопедагогических возможностях.

Определены следующие педагогические возможности клубной деятельности подростков Оренбуржья в 1930-1950-е годы для современной практики дополнительного образования: образовательные (расширение представлений подростков о творчестве, нравственности, гуманности, этике, эстетике, психологии); личностно-ориентированные (гуманистическая направленность, формирование личного опыта, факторы личностного самоопределения) и социально-педагогические возможности (самореализация подростков в групповых отношениях).

Образовательные педагогические возможности в реализовывались за счет расширения круга знаний подростков о творчестве, нравственности, гуманности, этике, эстетике, психологии, а также сведений о событиях, происходящих в стране, регионе и городе.

Представленные исторические факты, ранее приведенные в исследовании, свидетельствуют о том, что:

- подросткам предлагался широкий спектр деятельности в клубных объединениях;

осуществлялась помощь клубным объединениям как в материальнотехническом, так и методическом планах;

- организовывалось систематическое взаимодействие подростков с родителями и специалистами по отдельным профессиям.

Так, в Оренбуржье в 1938 году в кинотеатре р.п. Сорочинска открылась районная олимпиада по детской художественной самодеятельности[3]. Для подростков были организованы встречи с представителями культуры. Например, в 1951 году в Чкаловском Доме пионеров состоялась встреча учащихся с московскими артистами. Перед слушателями выступили Заслуженная артистка РСФСР Рина Зеленая, Лауреат Всесоюзного конкурса артистов эстрады Иван Шмелев, лауреат Всесоюзного конкурса музыкантов-исполнителей Наум Штарк и артист Борис Брунов[3]. Смотры художественной самодеятельности, творческие отчеты клубных объединений были повседневной практикой клубной деятельности.

В архивах сохранилась стенограмма областного совещания комсоргов школ и секретарей комитетов комсомола неполных средних и средних школ Оренбуржья, которое состоялось 15 декабря 1936 года. На нем отмечалось: «Вопрос культмассовой работы очень большой. Я хочу остановиться на 3-х моментах: работа кружков, как мы проводим перемены и подготовка к каникулам. Учитывая интерес, имеющийся у детей различного возраста, мы создали ряд кружков: физкультурный, хоровой, авиамодельный, драматический, шахматный. В физкультурном - больше учащихся старших классов. Проводим соревнования на лучшую команду класса. Большинство кружков работает под руководством самих учащихся.Учащихся вовлекли в систематическое чтение художественной литературы. Имеется библиотечный кружок. Учащиеся драмкружка готовятся к проведению Пушкинского юбилея» [4].

Такая клубная деятельность, осуществляемая при активности самих подростков, являлась творческой. Причем не только в художественной сфере, но и изобретательстве, создании действующих моделей и механизмов, выполнении трудовых и социальных обязанностей.

Важно положение, выдвинутое Я.А. Пономаревым, в котором утверждается, что применение индивидом известного решения к новому объекту является творческим актом[5]. Поэтому элементы творчества имела любая клубная деятельность подростков. Но, чтобы перенести известное действие на новый объект, следует это действие в начале усвоить. Поэтому пренебрегать репродуктивной деятельностью подростка, опыт которой является компонентом содержания образования, не следует. Так происходит обучение творчеству - вначале усвоение репродуктивной деятельности, затем 
многократное ее воспроизведение и, наконец, перенос на новый объект как творческий акт.

Сама же репродуктивная деятельность подростка становится возможной после усвоения им опыта познавательной деятельности, необходимой для получения информации о явлении. Такая информация усваивается как через систему специальных занятий, в том числе и в урочной деятельности, так и в любом познавательном взаимодействии - на экскурсиях, в беседах, при чтении книг, общении с другими носителями знаний.

В реальной практике клубной деятельности эти разные виды опыта (познавательного, репродуктивного, творческого) подростка обычно существуют нераздельно, а в совокупности, реализуясь совместно в разных ситуациях.

В художественной деятельности «важно восприятие подростком неповторимого чувственного облика предмета как носителя его души, выражение характера, судьбы, стремлений, родственной самому подростку внутренней жизни» [6]. Если отсутствует «сопричастное» отношение к предмету, к миру, то не получится произведение, стихотворение.

Занятия декоративно-прикладным творчеством помогают подростку глубже осознать чувство любви к Родине, осуществить поиск и создание новых декоративных форм, воспитывать умение мыслить нестандартно, дают возможность повысить общую культуру.

Подросток может заниматься литературным творчеством, которое заключается в создании литературных произведений (стихотворение, эссе, очерк).В литературном произведении, созданном им, должно быть самое главное - неповторимое содержание, попытка личностного решения проблемы, которая в этом возрасте тревожит каждого человека.

В современной музыкальной деятельности развиваются следующие виды творческих способностей:

- способность к продуктивному творчеству;

- способность к творческому восприятию музыки.

В клубной деятельности подростки активно занимаются техническим творчеством. Установлено, что приобретение научных, общих трудовых, общетехнических и специальных знаний и умений на занятиях по основам наук, трудового обучения и производственного труда должно идти параллельно с включением учащихся в творческую деятельность. При этом условии формирование и закрепление знаний и умений происходит значительно эффективней, так как подростки видят в них необходимость личностной самореализации.

В настоящее время определены эффективные методы, включающие моделирование продукта, проектирование манипуляторов, конструкторскую документацию с уменьшенным объемом данных, выполнение творческих задач, работу с изменением ранее созданных структур, эксперименты с мыслью, поиск и устранение неисправностей с помощью технических инструментов (включая симуляторы).

Научно-техническое творчество рассчитано на развитие исследовательских возможностей подростков с высоким уровнем познавательной активности, склонностью к исследовательской деятельности в области точных и естественных наук (физики, астрономии, математики).

Социально-педагогическое направление творчества призвано расширить знания подростков в области профессиональной деятельности, повысить общую и техническую культуру, психологическую и эмоциональную устойчивость.

Туристско-краеведческое творчество включает подростков в практические занятия по окружающему миру. Туризм и местная история - два взаимодополняющих средства, помогающих понять природные и культурные особенности среды. Туристическая работа основана на культурных и природных условиях региона, а 
краеведческая работа включает в себя такие формы туристической работы, как поход, экскурсия.

Эколого-биологическое творчество подростков не только предоставляет знания об окружающей среде и экологических проблемах, но и развивает способность принимать осознанные решения, которые направлены на изменение поведения людей в отношении окружающей среды.

В процессе занятий спортом происходит восстановление утраченных сил подростков, тем самым реализуется рекреационная функция досуга. Спорт-область социальной деятельности, представляющая собой совокупность духовных и материальных ценностей, создаваемых и используемых обществом в целях физического развития человека, укрепления его здоровья и совершенствования его двигательной активности.

Отметим, что в изучаемый в исследовании период (1930-1950-е годы) доминировала парадигма знания в образовании, которая определяла набор умений и навыков школьников. Вместе с тем передовые педагоги того времени понимали необходимость выхода за пределы такого набора содержания образования, главным образом, за счет реализации личностных потребностей. Эта задача реализовывалась в клубной деятельности, не только охватывающей все виды деятельности, но и основанной на эмоционально-ценностном отношении к ней.

Еще более существенные изменения в содержание образования вносила клубная деятельность при личностно-ориентированной трактовке ее компонентного состава. Все четыре вида опыта (познавательной деятельности, репродуктивной деятельности, творческой деятельности, эмоционально-ценностных отношений) не просто всесторонне раскрывались в клубной деятельности, но становились принципиально необходимыми для ее осуществления.

Выделим, что клубная деятельность подростков имплицитно, то есть по своей сути, содержит личностно-ориентированные возможности развития ее субъектов, которые иногда, даже вопреки обстоятельствам, реализуются в конкретных проектах и программах. Клубная деятельность не просто комплекс разных видов деятельности, а особый вид деятельности по самореализации подростков в групповых отношениях, которые направлены на утверждение самостоятельной ценности личности при сохранении свободы всех участников клуба.

Выделим факторы реализации гуманистической направленности клубной деятельности подростков[7]:

$\begin{array}{ll}\text { - } & \text { добровольность включения подростков в } \quad \text { различные виды } \\ & \text { деятельности; } \\ \text { - } & \text { вера педагога в каждого подростка; } \\ \text { - предупреждение негативных последствий } & \text { в педагогическом } \\ & \text { взаимодействии; } \\ \text { - обеспечение социальной защищенности подростков; } & \\ \text { - учет индивидуальных потребностей и интересов, предпочтений } \\ \text { подростков. }\end{array}$
правил:

При организации клубной деятельности подростков следует соблюдать ряд

- у учет активной позиции подростка;

- уважительное отношение к личности подростка;

- защита интересов воспитанников, непрерывный поиск оптимальных вариантов решения актуальных задач;

- формирование гуманных отношений в клубной деятельности подростков.

Таким образом, отражаются три главных направления современного воспитания: социокультурное, заключающееся в выборе и осуществлении образа жизни и 
поведения; индивидуальное, проявляющееся в самостановлении личности; сопричастное, характеризующееся выбором ценностей.

Организация работы клубных объединений в 1930 - 1950-е годы характеризуется гуманистической направленностью и разнообразием видов деятельности. Изучение историко-педагогической хроники событий позволяет подтвердить такой вывод. Так 25 августа 1935 года постановлением президиума облисполкома здание по улице Пионерской, дом 9. в г. Оренбурге передано для организации Дома пионеров им. XXI Международного юношеского дня[8]. На Никельстрое в г. Орске состоялся слет юных корреспондентов молодежных газет с участием корреспондентов области. В г. Оренбурге состоялось открытие шахматношашечного клуба с участием родителей и спортсменов. В 1936 году создан кружок ликвидации неграмотности и малограмотности в колхозе им. Баумана Секретарского района.

Особенно значимо общение подростков в клубной деятельности, которое по воспоминаниям ее участников позволяло реализовать ряд важнейших социальнопедагогических возможностей.

1. Ориентационная - формирование у подростков ценностного отношения к объектам окружающей действительности, выработка у них иерархии материальных и духовных ценностей.

2. Направляющая - профилактика асоциального поведения подростков и формирование мотивации к здоровому образу жизни. Реализация данной возможности выступает как реальное воздействие на практическую сторону жизни подростков, их поведение, выбор ими жизненного пути, постановку жизненных целей и их воплощение.

Если в 1930 - 1950-е годы в клубной деятельности подростков в Оренбуржье общение носило неформальный, мало регламентированный характер, то в настоящее время разработаны подробные рекомендации по его организации. Так, например, рекомендуется проводить час общения в клубном объединении.

Следовательно, образовательные, личностно-ориентированные и социальнопедагогические возможности клубной деятельности, стимулирующие процесс личностного самоопределения подростков, реализуются при выполнении следующих правил [9]:

a) учет индивидуальных и личностных особенностей развития и возрастной специфики личности подростка;

б) применение экологического подхода к самоопределению молодежи;

в) свободный выбор средств, форм и технологий социокультурной деятельности, отражающих реальные потребности и интересы подростков в процессе личного самоопределения.

Таким образом, педагогический потенциал клубной деятельности подростков Оренбуржья в 1930 - 1950-е годы для современной практики дополнительного образования, заключается в синтезе образовательных, личностно-ориентированных и социально-педагогических возможностей.

$$
* * *
$$

1. Митрахович, В.А. Потенциал как педагогическая категория / В.А. Митрахович // Известия Волгоградского государственного педагогического университета. - 2008. - С. 1-5.

2. Аллагулов, А.М. Роль педагогической науки в становлении образовательной политики в России во второй половине XIX - начале XX в. / А.М. Аллагулов // Известия Волгоградского государственного педагогического университета. - 2013. - № 5 (80). - С. 118-123.

3. Олимпиада художественной самодеятельности в Сорочинске // Колхозный труд. - 1937. - № 20.- С.4.

4. Встреча с московскими артистами // Чкаловская коммуна. - 1951. - № 78.- С.3.

5. Постановление Президиума ЦК ВОИЗа о работе всесоюзного общества изобретателей с юными техниками и изобретателями//ГБУ «ОГАСПИ». - Ф.1697. - Оп.1.- Д. 165. Л.25.

6. Психология одаренности детей и подростков / под ред. Н.С. Лейтеса.- М.: Академия, 1996. - 416 с. 
7. Сериков, В.В. Развитие личности в образовательном процессе / В.В. Сериков. - М.: Логос, 2012, - 448 c.

8. Постановление президиума облисполкома о передаче здания по ул. Пионерской, д. 9 в городе Оренбурге для организации Дома пионеров им. XXI Международного юношеского дня // ГБУ «ГАОО». - Ф. p. -1014. - Оп.1. - Д. 3. Л. 179.

9. Шилова, Н. А. Клубное объединение как среда личностного самоопределения подростков: автореф. дис. ... канд. пед. наук / Н.А. Шилова. - Санкт-Петербург, 2015. - 25с. 